\title{
Analysis of Public Interest in Sharia Investing Through Financial Technology Companies
}

\author{
Rizky Amelia*, Dedi Wibowo \\ Magister of Management \\ University of Indonesia \\ Jakarta, Indonesia \\ *rizkymel.32@gmail.com
}

\begin{abstract}
Nowadays, a trend is developing to seek the application of sharia law in every line of life, including in finance, especially investment. Given that Indonesia is the largest Muslim country in the world, it is the right place for the Islamic financial market share. But in reality, the share of the Islamic financial market is at $5 \%$ in 2018. Muslim investors are required to comply with ethical orders that are determined when making financial investments, which must be in accordance with Islamic principles, namely a ban on the use of Riba (interest), Maysir (gambling) and Gharar (uncertainty). On the other hand, the emergence of fintech which brings a new paradigm in which information technology is able to drive then create innovation in the financial industry. Fintech Syariah itself provides an alternative facility to transact Islamic financial products for the community. Therefore, in accordance with the literature which says that Islamic fintech is one way to be able to increase the market share of Islamic finance, the authors examine the public interest to invest in sharia through fintech. Using online questionnaires and respondents is not limited to just fintech users. The merging of the factors of perceived benefits, perceived risk, trust and perceived maqashid sharia were used in developing this research framework. As many as 202 respondents, the results of testing the data show that perceptions of benefits and perceptions of Islamic maqashid have a positive effect on the intention to invest in sharia through fintech.
\end{abstract}

Keywords-Islamic investment, Sharia fintech, perceived risk, perceived benefit, perceived maqashid sharia, trust, PLS-SEM

\section{INTRODUCTION}

Islam encourages its people to be able to produce their assets in economic activities and engage in business activities which are part of worship and obedience to God, using the principles of sharia [1]. Banking is one of the industries in which a Muslim can become part of economic activity, in this case what is meant is a Sharia Bank

Indonesia started Islamic banking since 1992, namely by establishing Muamalat Bank. However, Islamic finance in Indonesia is still below $6 \%$. Besides that, Islamic financial market only reached $8.69 \%$ of the total national financial market. The figure is as much as $5.94 \%$ representing the sharia banking market, while the remaining $2.75 \%$ is the non-sharia banking market. This condition is an anomaly considering Indonesia with the largest number of Muslims in the World with more than $87 \%$ of its population is Muslim. On the other hand, growing trends throughout the Muslim world to strive for the application of sharia law in every life, including investment. Muslim investors are obliged to obey the ethical orders specified when making financial investment, which must be in accordance with Islamic principles, such as the prohibition on the use of riba (interest), maysir (speculation/ unclear purpose), and gharar (uncertainty). Islam encourages wealth to be played in productive activities [2].

The emergence of fintech brings a new paradigm. Fintech is referred to as a game that is able to change, an innovation that is able to distort traditional financial market [3]. The presence of fintech is a new challenge for the traditional financial industry, including Islamic banking. Fintech have a very good market penetration power in attracting various customer segments, including the public which has been deemed unfit to be a bank customer, so that it will encourage the expansion of the Islamic financial industry.

Currently, in Indonesia, there is 164 fintech lending have been legalized by Otoritas Jasa Keuangan [4], including 12 sharia fintech. Sharia fintech is a platform that connects financing providers or capital owners (investors) with financing recipients (borrowers) to carry out financing agreements through internet. Sharia fintech business activities are prohibited contrary to Islamic principles.

The underlying reasons people want to invest through fintech if its benefits are greater than its risks. Customers want to determine the expected value of using fintech by considering the benefits and risks. Customers will use products or services if the benefits outweigh the risks, so fintech companies are challenged to increase the potential benefits of using fintech while limiting the potential risks [5].

Based on the description above, this research wants to explore the factors that influence people's interest in investing in sharia through financial technology companies. 


\section{LITERATURE REVIEW}

\section{A. Sharia Fintech}

According to DSN-MUI Fatwa 117/DSN-MUI/II/2018 concerning Information Technology-Based Financing Services Based on Sharia Principles defines sharia fintech as the provision of financial services based on sharia principles that bring together or connect Financing Providers with Financing Recipients in the context of conducting financing agreements through the system electronically by using an internet network. It was stated in the fatwa that sharia fintech business activities are prohibited from contradicting Islamic principles, which include avoiding riba (interest), gharar (unclear contract), maysir (unclear purpose/ speculation), tadlis (not transparent), dharar (danger), zhulm (loss of one party), and haram.

The projects and products offered by Islamic crowdfunding must be halal and in accordance with the sharia [6]. The determination of the halal status of a project or products is carried out by the Sharia Supervisory Board. In addition to the project or product being funded, it is also necessary to ensure that the funds invested to finance the project or product are halal. Thus, Islamic crowdfunding must conduct a feasibility analysis both in terms of sharia and financially.

\section{B. Perceived Benefit}

Perceived benefits can be felt by customers when a new service offers a higher value than existing services, such as increasing economic benefits obtained, comfort and customer satisfaction. Customers will compare the services available and choose the ones that have better value [7]. User motivation is classified as intrinsic and extrinsic factors. Extrinsic motivation refers to the performance of an activity to achieve certain goals, while intrinsic motivation refers to the performance of an activity without a clear purpose other than the process of the activity itself [8]. Both of these factors have been found in several studies as factors that influence perceived benefit and behavioural intentions.

This study refers to extrinsic motivation, because fintech users tend to use fintech for their utilitarian benefits, rather than merely getting hedonic benefits. Therefore, this study purposes two extrinsic motivations as components of perceived benefits, namely economic benefits and seamless transactions.) In the context of fintech, these economic benefits include the reduction of costs and financial benefits from some fintech transactions.

Whereas unlimited transactions refer to the benefits associated with transactions using fintech, for example in this study is lending or investing [5]. A smooth process is essential for transaction through fintech to replace the services of traditional financial institutions. This allow customers to transact with fintech, which offers simple and fast financial transactions [9].

\section{Perceived Risk}

Risk perception is a fundamental obstacle in using fintech services. In some previous studies, risk perception negatively influenced intention to use IT services [10]. In the study of consumer behaviour, perceived risk is the probability of uncertainty when deciding to buy and the consequences or consequences that may occur [11]. This risk perception is especially relevant to intangible products related to online transactions.

In connection with this research, there is a risk of insufficient infrastructure capacity in a fintech company which has a negative influence on online financial transactions. This lack of infrastructure capacity can trigger risk perceptions when investing in peer to peer lending in fintech. This risk perception involves the expectations arising from investing money in fintech companies, so it is proposed two components of risk perception, namely financial risk and security risk.

Financial risk refers to the existence of potential financial losses in transactions using fintech [12]. This financial loss from fintech is caused by the malfunction of the financial transaction system, financial fraud, and the additional transaction costs of the initial price that affect the intention to use fintech [9].

Whereas security risk is interpreted as a potential loss due to fraud or hacking that endangers the security of fintech transactions. This risk can be a violation of privacy which is a critical problem for customers. These scams and hackers can cause loss of user money and violate user privacy [10].

\section{Trust}

The definition of trust after the emergence of the internet is when one party has trust as a form of exchange for the reliability and integrity of the other party [13]. Trust is the most important component in any relationship, plays an important role in many social and economic interactions as does crowdfunding which involves uncertainty and dependence [14]. Many previous studies have proven that trust significantly influences individual behaviour [15].

Institutional / organizational / platform-based trust is trust based on guarantees and recommendations from third parties. In this case when there is no experience from the fund owner (investor), trust can be built through institutional mechanisms such as certification. This certification is related to licensing and accreditation which can prove the ability of expected behaviour from trusted parties. The existence of digital certification has been proven to be able to build trust [16].

\section{E. Perceived Maqashid Sharia}

Perceived maqoshid sharia is a relatively new construct and has not been widely discussed. Current mainstream thinking manifests the Islamic maqoshid in the science of ushul fiqh. Basically maqoshid sharia is understood and perceived rationally, goal oriented, and rules based on the scriptures both textually and contextually [17]. Khamis tried to develop 
measurements of religious values based on the Islamic maqashid approach [18]. The results of the study confirm that the concept of maqashid sharia can be reduced to a measurable indicator. One example is the belief that profits and losses in business are sustenance from Allah SWT. That trust is an indicator of the aspects of hifzhu maal in sharia maqoshid.

The perception of maqashid sharia in connection with transactions on fintech can be understood as consumers' perception of how the fintech company implements sharia maqashid which is reflected in the services offered in accordance with sharia principles. One example of this perception is that there is no interest on loans (riba) and payment of zakat of the owner of funds set aside from profits [19], how customers assess whether Islamic fintech has good prospects in the future or not [20].

Customers in this case as investors who invest their capital in Islamic fintech with economic motives, namely the development of the invested capital. The Islamic perspective can be understood that the wealth obtained is a gift from God and a temporary trust in humans, so adding wealth must be done using lawful means [2].

\section{F. Hypothesis Development Research}

Based literature review on the previously discussed, the researcher built a framework of thought composed by four main factors, consisting of: (1) trust; (2) perceived benefit; (3) perceived risk and (4) perceived maqashid sharia as a determinant in shaping consumer investment decisions through sharia fintech. The model used in this study is structured as shown in figure 1:

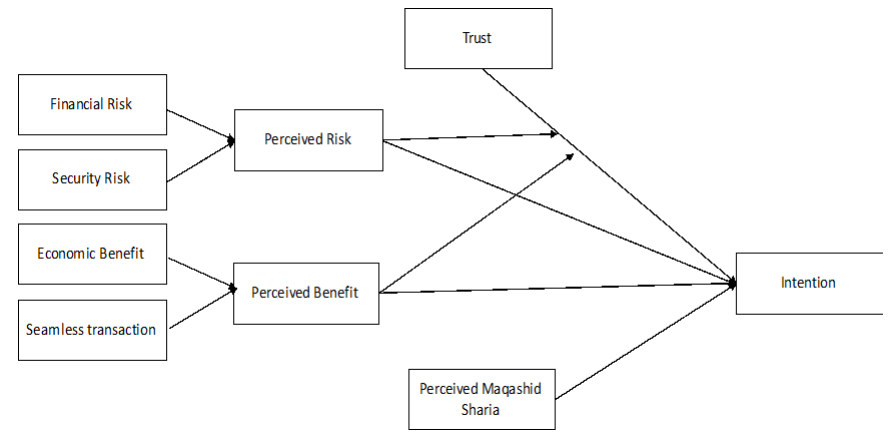

Fig. 1. Conceptual framework.

Many previous studies have shown that trust significantly influences individual behaviour [15]. Based on research by Pavlou and Gefen [21], it is mentioned that trust impacts behaviour and attitudes of decision making. In the study, they surveyed 127 respondents who had used the Amazon.com shopping site and examined the relationship between trust and consumer behaviour. Based on this, the authors propose the following hypothesis:

H1: Trust in fintech companies has a positive effect on investment intentions
Perceived Risk is a fundamental obstacle in using fintech services. In some previous studies, perceived risk negatively affects intentions [10]. Based on this, the authors propose the following hypothesis:

H2: Perceived Risk has a positive effect on investment intentions

Perceived benefits can be felt by customers when a new service offers a higher value than existing services, such as increasing economic benefits obtained, comfort and customer satisfaction. Customers will compare the services available and choose the ones that have better value [7]. Based on this, the authors propose the following hypothesis:

H3: Perceived benefits have a positive effect on investment intentions

The perceived Maqashid sharia is considered in choosing an instrument and place of investment. In this case the perceived Maqashid sharia means how consumers perceive sharia fintech in carrying out religious values. Based on this, the authors propose the following hypothesis:

H4: Perceived Maqashid sharia has a positive effect on investment intentions

In addition to incorporating the dimensions of trust, perceived risk, perceived benefits, and perceived Maqashid sharia as factors that influence respondents' decisions to invest in sharia through fintech, this study also includes moderation factors as follows:

H5: Perceived risk moderates the relationship between trust and investment intentions

H6: Perceived benefits moderate the relationship between trust and investment intentions

\section{METHODS}

This study uses a quantitative approach, with the aim to determine consumer perceptions of investment decisions through the trust approach. The survey, which was conducted using a questionnaire, was carried out online through social media, by distributing questionnaire links to prospective respondents. Before the questionnaire was distributed, the preliminary test was performed by 59 respondents. Likert scale 1-5 (Strongly Disagree, Disagree, Neutral, Agree, Strongly Agree) is used as a measurement of the research instrument used. Data processing method using PLS-SEM to understand relation between variables.

The majority of respondent were male $(60.40 \%)$ with women representing $39.60 \%$ of respondents. Of all participants, $55.45 \%$ were in the age group of 30-34 years, and $53.96 \%$ had a master's degree and above. As for occupational status, $45.05 \%$ of the respondents worked in the public sector, $25.25 \%$ were in the private sector. For monthly expenses, $44.06 \%$ of the respondents spend more than Rp 10 million per month, $23.76 \%$ spend more than $\mathrm{Rp} 7-10$ million. 
Stages of analysis using PLS-SEM must at least pass five processes, which are conceptualizing the model, determining the algorithmic analysis method, determining the resampling method, drawing the path diagram, evaluating the outer model or measurement model, and evaluate inner model or structural model. All indicators meet the acceptable loading factor value limit, which is more than equal to 0.70 .

After examining the loading factor value, the next stage of convergent validity is internal consistency or construct reliability. Reliability rest aims to determine the level of data consistency of research indicators. Reliability test can be seen for two things, which are Cronbach's Alpha (CA) and Composite Reliability (CR) values, the indicator is reliable if the value of CA and CR is greater than 0.7.

As shown in Table below, it can be explained that all indicators can be used in factor analysis testing because they have anti-image correlation values greater than 0.5 .

TABLE I. VALIDITY AND RELIABILITY TEST

\begin{tabular}{|c|c|c|c|c|}
\hline Latent & Indicators & Loadings & Composite & AVE \\
\hline \multirow[t]{3}{*}{ Financial Risk } & PE1 & 0,960 & \multirow[t]{3}{*}{0,960} & \multirow[t]{3}{*}{0,889} \\
\hline & PE2 & 0,922 & & \\
\hline & PE3 & 0,947 & & \\
\hline \multirow[t]{6}{*}{ Security Risk } & EE1 & 0,808 & \multirow[t]{6}{*}{0,936} & \multirow[t]{6}{*}{0,831} \\
\hline & EE2 & 0,957 & & \\
\hline & EE3 & 0,961 & & \\
\hline & PV2 & 0,965 & & \\
\hline & PV3 & 0,971 & & \\
\hline & HT2 & 0,955 & & \\
\hline \multirow[t]{3}{*}{ Economic Benefit } & EB1 & 0,960 & \multirow[t]{3}{*}{0,960} & \multirow[t]{3}{*}{0,889} \\
\hline & EB2 & 0,922 & & \\
\hline & EB3 & 0,947 & & \\
\hline \multirow{3}{*}{$\begin{array}{c}\text { Seamless } \\
\text { Transaction }\end{array}$} & ST1 & 0,808 & \multirow[t]{3}{*}{0,936} & \multirow[t]{3}{*}{0,831} \\
\hline & ST2 & 0,957 & & \\
\hline & ST3 & 0,961 & & \\
\hline \multirow{3}{*}{$\begin{array}{l}\text { Trust In } \\
\text { Platform }\end{array}$} & TR1 & 0,856 & \multirow[t]{3}{*}{0,921} & \multirow[t]{3}{*}{0,795} \\
\hline & TR2 & 0,916 & & \\
\hline & TR3 & 0,902 & & \\
\hline \multirow{3}{*}{$\begin{array}{c}\text { Intention Using } \\
\text { Fintech }\end{array}$} & IB1 & 0,952 & \multirow[t]{3}{*}{0,944} & \multirow[t]{3}{*}{0,849} \\
\hline & IB2 & 0,951 & & \\
\hline & IB3 & 0,859 & & \\
\hline
\end{tabular}

Table 1 shows that constructs related to perceived risk, perceived benefit, trust and perceived maqashid sharia have met the aspects of reliability and validity, because the composite reliability values of these constructs are greater than 0.7, and the value of AVE has fulfilled criteria greater than 0.5.

\section{RESULTS AND DISCUSSION}

\section{A. Result}

The majority of respondent were male $(60.40 \%)$ with women representing $39.60 \%$ of respondents. Of all participants, $55.45 \%$ were in the age group of 30-34 years, and $53.96 \%$ had a master's degree and above. As for occupational status, $45.05 \%$ of the respondents worked in the public sector, $25.25 \%$ were in the private sector. For monthly expenses,
$44.06 \%$ of the respondents spend more than $\mathrm{Rp} 10$ million per month, $23.76 \%$ spend more than $\operatorname{Rp} 7-10$ million.

The results of data processing are carried out to test the hypothesis, as described in Table 2 below:

TABLE II. RESUltS OF STRUCTURAL MODEL

\begin{tabular}{|l|l|l|l|l|}
\hline No. & \multicolumn{1}{|c|}{ Hypothesis } & $\begin{array}{c}\text { T } \\
\text { Statistics }\end{array}$ & $\begin{array}{c}\text { P } \\
\text { Value }\end{array}$ & Result \\
\hline H1 & $\begin{array}{l}\text { Trust in fintech companies has a } \\
\text { positive effect on investment } \\
\text { intentions }\end{array}$ & 0.033 & 0.974 & $\begin{array}{l}\text { Not } \\
\text { Significant }\end{array}$ \\
\hline H2 & $\begin{array}{l}\text { Perceived Risk has a positive } \\
\text { effect on investment intentions }\end{array}$ & 1.133 & 0.004 & Significant \\
\hline H3 & $\begin{array}{l}\text { Perceived benefits have a } \\
\text { positive effect on investment } \\
\text { intentions }\end{array}$ & $\begin{array}{l}\text { 2.277 } \\
\text { Perceived Maqashid sharia has a } \\
\text { positive effect on investment } \\
\text { intentions }\end{array}$ & 0.023 & Significant \\
\hline Moderating Effect & $\begin{array}{l}\text { Perceived risk moderates the } \\
\text { relationship between trust and } \\
\text { investment intentions }\end{array}$ & 2.168 & 0.009 & $\begin{array}{l}\text { Not } \\
\text { Significant }\end{array}$ \\
\hline H6 & $\begin{array}{l}\text { Perceived benefits moderate the } \\
\text { relationship between trust and } \\
\text { investment intentions }\end{array}$ & 0.373 & 0.709 & $\begin{array}{l}\text { Not } \\
\text { Significant }\end{array}$ \\
\hline
\end{tabular}

\section{B. Discussion}

Respondents' trust in companies that offer fintech services has a positive but not significant effect on the intention to invest through fintech. Positive influence because respondents feel safe using the services of a fintech company overseen by Bank Indonesia (BI) and Otoritas Jasa Keuangan (OJK). But on the other hand, the company's reputation is a consideration for respondents to feel confident with a fintech company. This is due to lack of information regarding fintech companies. So that trust does not have a positive but significant effect on investment intentions.

Perceived risk is a fundamental obstacle in using fintech services. In some previous studies, perceived risk negatively affects intentions [10]. Respondents felt that the risk of investing using fintech was higher than through traditional financial services. So, the perceived risk does not significantly affect investment intentions.

Perceived benefits has a positive and significant effect on investment intentions. Perceived benefits can be felt by customers when a new service offers a higher value than existing services, such as increasing economic benefits obtained, comfort and customer satisfaction. In context of fintech, these economic benefits include reduced costs and financial benefits from several fintech transactions. Some fintech applications offer users lower transaction fees than traditional financial services, in addition to peer to peer or crowdfunding lending services also provide higher returns to lenders [22]. Respondents feel that the benefits gained by investing through fintech outweigh the risks, such as higher returns, lower transaction costs, ease and effectiveness of time and effort. The same results also affect the moderation of the 
perception of benefits have a positive and significant effect on the relationship between trust and investment intentions.

Respondents are of the opinion that the sharia financial market share will develop in the future, so investing in sharia through fintech is one way to safeguard its assets. In addition, issuing zakat is a way to safeguard the world's treasures. By investing in sharia through fintech, respondents feel they can use the gift of reason given by God by choosing halal financial transactions. In addition, respondents can invest while getting information / knowledge about halal financial transactions through fintech companies. As suggested by the results, perceived maqashid sharia has a positive and significant effect on investment intention.

\section{CONCLUSION}

The conclusion of this study is there is a consideration between the costs incurred with the benefits obtained by respondents in the decision to invest sharia through fintech. Financial transaction services through fintech that offer transaction cost efficiencies and other costs incurred compared to traditional transactions through banks. Furthermore, from the perspective of sharia, the factor of preserving religion is the factor that has the highest influence on the intention to invest in sharia through fintech.

Due to the limitations in this study and the existence of research results that are different from previous studies, therefore the advice that can be given are for fintech companies, they can conduct socialization related to the benefits and risks in conducting transactions through fintech. Because transactions involve funds as an investment, there is a sense of security when dealing with transactions and contracts face to face/ visually. Moreover, companies in collaboration with interested parties in the Islamic financial industry, they can hold workshops or discussion forums to build and increase public awareness of the obligation to transact in accordance with sharia principles. For further research, it can test different age groups with equitable distribution. Also expected to be able to expand the model that has been applied in this study to predict interest in investing in sharia through fintech, one way can include moderation variables to comprehensively predict public interest. And the last for the maqashid dimension of sharia needs to be deepened again regarding people's perception of how fintech companies carry out sharia values in practice.

\section{REFERENCES}

[1] A. Fathonih, G. Anggadwita and S. Ibraimi, "Sharia venture capital as financing alternative of Muslim entrepreneurs," $J$ Enterprising Communities People Places Glob Econ, vol. 13, no. 3, pp. 333-352, 2019.

[2] M.A. Laldin and H. Furqani, "Developing Islamic finance in the framework of maqasid al-Shari'ah," International Journal of Islamic and Middle Eastern Finance and Management, 2013.
[3] T.H. Lee and H.W. Kim, "An exploratory study on fintech industry in Korea: crowdfunding case," 2nd International conference on innovative engineering technologies (ICIET'2015) Bangkok, 2015.

[4] OJK, Statistik Fintech Lending Periode Desember 2019, 2019.

[5] H.S. Ryu, "What makes users willing or hesitant to use Fintech?: the moderating effect of user type," Ind Manag Data Syst., vol. 118, no. 3, pp. 541-569, 2018.

[6] S.I. Wahjono, A. Marina and W. Widayat, "Islamic Crowdfunding Alternative Funding Solution," 1st World Islam Soc Sci Congr., 2015.

[7] D.J. Kim, D.L. Ferrin and H.R. Rao, "A trust-based consumer decisionmaking model in electronic commerce: The role of trust, perceived risk, and their antecedents," Decis Support Syst., 2008.

[8] F.D. Davis, R.P. Bagozzi and P.R. Warshaw, "User Acceptance of Computer Technology: A Comparison of Two Theoretical Models," Manage Sci., 1989.

[9] L. Zavolokina, G. Schwabe and M. Dolata, "FinTech - What's in Name?" Thirty Seventh International Conference on Information Systems, pp. 1-19, 2016.

[10] E. Lee and B. Lee, "Herding behavior in online P2P lending: An empirical investigation," Electron Commer Res Appl., 2012.

[11] J. Choi , A. Lee and C. Ok, "The Effects of Consumers' Perceived Risk and Benefit on Attitude and Behavioral Intention: A Study of Street Food," J Travel Tour Mark, 2013.

[12] S. Forsythe, C. Liu, D. Shannon, and L.C. Gardner, "Development of a scale to measure the perceived benefits and risks of online shopping," $J$ Interact Mark., 2006.

[13] Morgan RM, Hunt SD. The Commitment-Trust Theory of Relationship Marketing. J Mark. 1994;

[14] M. Kang , Y. Gao, T. Wang and H. Zheng, "Understanding the determinants of funders' investment intentions on crowdfunding platforms: A trust-based perspective," Ind Manag Data Syst., 2016.

[15] Y.H. Chen, T.P. Lin and D.C. Yen, "How to facilitate interorganizational knowledge sharing: The impact of trust," Inf Manag., vol. 51, no. 5, pp. 568-578, 2014.

[16] X. Luo, "Trust production and privacy concerns on the Internet: A framework based on relationship marketing and social exchange theory," Ind Mark Manag., 2002.

[17] M.H. Kamali, "Maqasid Al-Shari'ah Made Simple," Int Inst Islam Thought, 2014.

[18] M.R. Khamis, "Measuring Religious Values Development Based on Maqasid Syariah Approach in Compliance Behavior of Business Zakat Scenario," Adv Bus Res Int J., 2016.

[19] Y. Olufadi, "Muslim Daily Religiosity Assessment Scale (MUDRAS): A new instrument for Muslim religiosity research and practice," Psycholog Relig Spiritual, vol. 9, no. 2, pp. 165-179, 2017.

[20] M. Loo, "Attitudes and Perceptions towards Islamic Banking among Muslims and Non-Muslims in Malaysia: Implications for Marketing to Baby Boomers and X-Generation," Int J Arts Sci., 2010.

[21] P.A. Pavlou and D. Gefen, "Building effective online marketplaces with institution-based trust," Information systems research, vol. 15, no. 1, pp. 37-59, 2004.

[22] E.M. Gerber, J.S. Hui and P.Y. Kuo, "Crowdfunding: Why people are motivated to post and fund projects on crowdfunding platforms," Proceedings of the international workshop on design, influence, and social technologies: techniques, impacts and ethics, vol. 2, no. 11, pp. 10, 2012. 